\section{Improving our understanding of LIP emplacement ages using petrology, thermal modelling, and geochemistry of zircon crystals: a case study from the Central Atlantic Magmatic Province}

JOSHUA H.F.L. DAVIES ${ }^{1}$, ANDREA MARZOLI ${ }^{2}$, HERVE BERTRAND $^{3}$, NASRRDDINE YOUBI ${ }^{4}$, MARCIA

ERNESTO $^{5}$, DR. NICOLAS DAVID GREBER ${ }^{6}$, MICHAEL $^{2}$ ACKERSON $^{7}$, GUY SIMPSON ${ }^{8}$, DR. ANNE-SOPHIE

BOUVIER, PHD ${ }^{9}$, LUKAS P. BAUMGARTNER ${ }^{10}$, THOMAS PETTKE $^{6}$, FEDERICO FARINA ${ }^{11}$ AND PROF. URS SCHALTEGGER, PHD $^{8}$

${ }^{1}$ Université de Québec à Montréal

${ }^{2}$ University of Padova

${ }^{3}$ ENS Lyon

${ }^{4}$ Cadi Ayyad University

${ }^{5}$ Universidade de São Paulo

${ }^{6}$ University of Bern

${ }^{7}$ Smithsonian National Museum of Natural History

${ }^{8}$ University of Geneva

${ }^{9}$ ISTE - University of Lausanne

${ }^{10}$ University of Lausanne

${ }^{11}$ Università degli Studi di Milano

Presenting Author: davies.joshua@uqam.ca

The precise and accurate determination of the emplacement age of large igneous provinces (LIP) is crucially important to assess the links between these magmatic events and mass extinctions. Such data are typically obtained from zircon CA-IDTIMS U-Pb analyses, however, why zircon crystallizes in these magmas is not clearly understood, since their mafic composition should limit zircon saturation. Also, data from LIP magmas can have complex U-Pb age distributions, especially if both baddeleyite and zircon are analyzed, and determining the emplacement age from such distributions is non-trivial.

Here we use a combination of petrology, elemental and isotopic $(\mathrm{O}, \mathrm{Hf}, \mathrm{U}-\mathrm{Pb})$ and thermal modelling to investigate why zircon crystalizes in LIP magmas, using the Central Atlantic Magmatic Province (CAMP) as an example. We also suggest the best way to interpret the $\mathrm{U}-\mathrm{Pb}$ age data.

We show that upper crustal assimilation, especially of shales, during the emplacement of the CAMP magmas could have facilitated zircon saturation, the assimilation of upper crustal sediments is also supported by high oxygen isotope values and negative $\varepsilon \mathrm{Hf}$ values in zircon crystals. Zircon from the North Mountain basalt in Nova Scotia, Canada contains a large age variation in its zircon crystals (up to $4 \mathrm{Ma}$ ), and the older crystals have slightly more negative $\mathrm{EHf}$ values suggesting the presence of small (micron scale) xenocrystic cores associated with late stage sediment assimilation. The CAMP dataset as a whole suggests, however, that in general, xenocrystic cores in CAMP zircon are rare. Assuming that no xenocrystic cores are present, and considering that the mafic CAMP magmas are zircon undersaturated for most of their crystallization history, the oldest zircon age cluster in a population should record the magma emplacement (or time when assimilation occurred). Zircon ages younger than the oldest cluster are more likely to reflect $\mathrm{Pb}$ loss, especially given the high U concentrations of LIP zircon. The combination of both, older $\mathrm{Pb}$ components from crustal assimilation and younger apparent ages from $\mathrm{Pb}$ loss, may hamper the unequivocal interpretation of a complex age distribution in terms of an emplacement age. 